\title{
ANALISIS KEBUDAYAAN JEPANG TENTANG PERAYAAN OSHOGATSU
}

\author{
Marly Masoko \\ Universitas Negeri Manado \\ marlymasoko@unima.ac.id
}

\begin{abstract}
Abstrak
Kegiatan ini bertujuan meningkatkan pengetahuan Generasi muda yang ada didesa Koya Kabupaten Minahasa tentang bahasa Jepang dalam hal ini tentang guiding yang berisi percakapan praktis yang baik dan benar dan kebudayaan Jepang Oshogatsu untuk membekali pengetahuan pembelajaran bahasa Jepang praktis dan huruf Jepang yang efektif. Metode yang digunakan dalam kegiatan pembelajaran Bahasa Jepang praktis ini yang dilaksanakan dengan menggunakan metode Active learning dengan pokok permasalahan yang disesuaikan dengan tujuan yang ingin dicapai adalah yaitu metode active learning dengan menggunakan multimedia. Dengan adanya kegiatan pelatihan ini diharapkan dapat memberikan pengetahuan bahasa Jepang kepada Generasi muda yang ada didesa Koya Kabupaten Minahasa dan peningkatan kualitas sumber daya manusia melalui kegiatan-kegiatan kemasyarakatan.
\end{abstract}

Kata kunci: Oshogatsu, active learning

\section{PENDAHULUAN}

\section{A. Analisis Situasi :}

Pemuda dalam tiap masa selalu
menjadi tulang punggung sebuah perubahan. Apakah itu perubahan menuju lebih baik atau sebaliknya. Pemuda dalam definisi sosial adalah generasi antara umur 20 - 40 tahun ( atau 18- 35 tahun dalam referensi lain). Dalam kajian ilmu sosial, puncak kematangan peran publik seorang manusia ialah antara umur 40 -60 tahun. Dari perbandingan di atas, kita dapat menyimpulkan, bahwa pemuda adalah penerus generasi sebelumnya untuk masa yang akan datang. Pembangunan pendidikan dan pengembangan generasi muda merupakan bagian integral dari upaya pengembangan sumber daya manusia di berbagai bidang.

Rahasia berikutnya adalah keunggulan mengorganisasi kekuatan. Ada setidaknya lima faktor prinsip yang dipegang pemuda, dalam mengorganisasi kekuatan mereka, yaitu :

1. Kekuatan asas perjuangan

2. Kekuatan konsep dan metode perjuangan

3. Kekuatan persatuan

4. Kekuatan sikap dan posisi perjuangan

5. Kekuatan aksi dan opini : memiliki isu sentral, konsistensi misi, imun dalam perjuangan, kesinambungan aksi dan opini. 
Disaat kondisi bangsa seperti saat ini peranan pemuda atau generasi muda sebagai pilar, penggerak dan pengawal jalannya reformasi dan pembangunan sangat diharapkan. Dengan organisasi dan jaringannya yang luas, pemuda dan generasi muda dapat memainkan peran yang lebih besar untuk mengawal jalannya reformasi dan pembangunan. Permasalahan yang dihadapi saat ini justru banyak generasi muda atau pemuda yang mengalami disorientasi, dislokasi dan terlibat pada kepentingan politik praktis. Seharusnya melalui generasi muda atau pemuda terlahir inspirasi untuk mengatasi berbagai kondisi dan permasalahan yang yang ada. Pemuda atau generasi muda yang mendominasi populasi penduduk Indonesia saat ini mesti mengambil peran sentral dalam berbagai bidang untuk kemajuanUntuk itu dibutuhkan peran aktif pemuda dan remaja dalam menunjang sektor pariwisata.

Setiap negara di dunia memiliki kebudayaan yang beraneka ragam, unik dan khas tidak terkecuali negara Jepang. Jepang merupakan salah satu negara Asia Timur yang kebudayaannya terkenal dengan ciri khasnya yang unik dan banyak diminati oleh orang-orang di berbagai negara termasuk Indonesia. Jepang dikenal sebagai bangsa yang berbudaya tinggi karena walaupun Jepang merupakan negara yang maju, masyarakat Jepang tetap mempertahankan dan memelihara kebudayaannya.

Rakyat Jepang pada dasarnya konservatif yaitu suatu bangsa yang berusaha memelihara dan meneruskan nilai-nilainya sendiri. Tetapi di lain pihak, sifat rakyat Jepang menunjukkan naluri yang amat kuat untuk menjamin kelangsungan hidupnya. Karena itu ia didorong untuk menerima atau bahkan mengambil hal-hal baru dari luar, jika halhal itu dirasakan bermanfaat untuk kelangsungan hidupnya.( Suryohadiprojo, 1982:192-193)

Kebudayaan adalah keseluruhan sistem gagasan, tindakan dan hasil karya manusia dalam rangka kehidupan masyarakat yang dijadikan milik diri manusia dengan belajar (Koentjaraningrat,1996:72). Kebudayaan atau yang dapat disebut juga "Peradaban" mengandung pengertian yang sangat luas dan mengandung pemahaman perasaan suatu bangsa yang sangat kompleks meliputi pengetahuan, kepercayaan, seni, moral, hukum, adat-istiadat, kebiasaan dan pembawaan lainnya yang diperoleh dari anggota masyarakat. (Taylor, 1897:19) Jepang merupakan negara yang memiliki empat musim yaitu: musim semi $\begin{gathered}\text { はる } \\ \text { (春 }\end{gathered}$ ),musim panas( 夏 $)$,musim gugur ( 秋き $)$ dan musim dingin (冬). Disetiap musimnya dalam setahun terdapat berbagai macam 
perayaan dan upacara-upacara yang hingga saat ini masih dilaksanakan. Beberapa diantaranya yaitu: tanabata, hina matsuri, tango no sekku dan festival-festival lainnya. (Sudjianto, $2002:$ 52)

Perayaan serta upacara-upacara yang ada di Jepang pada dasarnya dibagi menjadi dua kategori umum, yaitu: matsuri (㿟り) yang biasa diartikan festival dan nenchu gyoji (年中行事) yang berarti kegiatan tahunan. (Kodansha, 2003:526). Nenchu gyoji ( 年中行事) secara harafiah diartikan sebagai acara atau perayaan tahunan dan musiman. Nenchu gyoji ( ねんちゅうぎょうじ) sering pula disebut nenju gyoji ( ねんじゅうぎょうじ). Nenju ( ねんじゅう

年中) berarti sepanjang tahun, sedangkan gyoji (行事) berarti upacara atau perayaan. Bentuk dari perayaan nenchu gyoji ini pertama kali digunakan pada zaman Heian (794-1185). Hal yang membedakan nenchu gyoji dengan matsuri adalah, bila matsuri merupakan perayaan asli yang terlahir dari budaya bangsa Jepang, sedangkan kalau nenchu gyoji kebanyakan perayaan dan acaranya berasal dari negara China dan agama Buddha.

Oshogatsu (お年月が kebudayaan Jepang yaitu salah satu nenchu gyoji 'perayaan tahunan' yang sangat penting dan yang paling ditunggu-tunggu oleh masyarakat Jepang. (Gilhooly, 2002: 104). Oshogatsu berlangsung di tanggal 1-3 Januari. Oleh karena itu bank, kantor pemerintahan, dan hampir semua perusahaan dan toko di tutup. Pada tanggal ini adalah waktunya warga Jepang berkumpul bersama keluarga untuk merayakan tahun baru. (KIRJSL,1992) Pada awal tahun baru masyarakat Jepang pergi ke kuil. Kunjungan pertama ke kuil sebelum fajar di hari tahun baru ini disebut hatsumoude ( $\left.\begin{array}{c}\text { はっもうで } \\ \text { 初詣 }\end{array}\right)$, yang berarti kunjungan pertama. Di kuil ini mereka meminta berkah untuk tahun yang baru dan mengambil undian berupa kertas ramalan yang disebut omikuji (御神籤). Kemudian saat gantan (元旦) 'hari pertama tahun baru' orang Jepang bersama keluarga memakan memulai dengan sarapan mochi atau kue dari beras ketan. Kue beras disajikan dalam sup yang disebut Ozoni (お ぞうに khusus untuk tahun baru yang disiapkan pada saat Omisoka (大脢日) yaitu Osechi ryori (おせち料理). Masakan ini merupakan makanan campur-campur yang berwarnawarni dan rasanya manis terdiri atas udang, telur, rumput laut, rebung, ikan, mochi, dan lainnya. Osechi ryori (おせち料理)

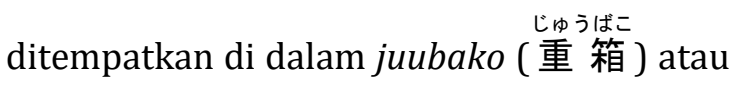


semacam kotak bento bertingkat. Osechi ini berupa satu set masakan dari beberapa menu yang masing-masing punya arti tertentu seperti kuromame ( 墨票) 'kacang hitam sama dengan lambang kesehatan', kombu (昆布) 'seaweed atau rumput laut yang berarti kebahagiaan', ada yang kuningkuning seperti telur atau chesnut (yang berarti matahari/emas) ada juga udang (artinya hidup sehat sampe tua/bungkuk), ikan teri (artinya banyak keturunan), renkon ( 蓮根) 'akar lotus yg berlubanglubang berarti lihat kedepan', dan seterusnya. Tradisi penyiapan masakan ini dimulai sejak masa Heian (794-1185).(Upik Kesumawati Hadi, 2011: 2)

B. Permasalahan Mitra

Sebagai mitra dalam pelaksanaan kegiatan pengabdian pada masyarakat ini adalah Para pemuda didesa Koya. Permasalahan yang teridentifikasi yang menjadi titik tolak kegiatan pengabdian pada masyarakat yang diusulkan ini terfokus pada beberapa masalah yang dihadapi oleh mitra yaitu :

1. Bagaimana bentuk pengajaran budaya Jepang perayaan Oshogatsu dan apa saja tradisi yang ada pada saat Oshogatsu?

2. Kontribusi dalam pembelajaran bahasa Jepang

\section{TARGET DAN LUARAN}

A. Target :

Berdasarkan latar belakang pemikiran dan konteks permasalahan yang ada, maka pelaksanaan pelatihan ini bertujuan, Tujuan kegiatan yang ingin dicapai melalui kegiatan pengabdian ini adalah untuk meningkatkan pengetahuan Generasi muda yang ada didesa Koya Kabupaten Minahasa tentang bahasa Jepang dalam hal ini tentang guiding yang berisi percakapan praktis yang baik dan benar dan kebudayaan Jepang Oshogatsu. Pengetahuan yang diberikan berkenaan dengan menunjang pariwisata yang ada diSulawesi Utara yang artinya dibutuhkan keterampilan berbicara yang baik sebagai modal dalam berkomunikasi dengan wisatawan.

$$
\text { Dengan adanya kegiatan pelatihan }
$$
ini diharapkan dapat memberikan pengetahuan bahasa Jepang kepada Generasi muda yang ada didesa Koya Kabupaten Minahasa dan peningkatan kualitas sumber daya manusia melalui kegiatan-kegiatan kemasyarakatan.

B. Luaran

Luaran yang diharapkan melalui pelaksanaan kegiatan pengabdian pada masyarakat ini adalah sebagai berikut :

1. Peningkatan kualitas sumber daya manusia yakni Generasi 
muda yang ada didesa Koya Kabupaten Minahasa

2. Melalui kegiatan ini diharapkan para Generasi muda yang ada didesa Koya Kabupaten Minahasa dapat memiliki pengetahuan yang positif dalam rangka upaya peningkatan kemampuan Bahasa Jepang Praktis dan mengetahui dan kebudayaan Jepang Oshogatsu

\section{METODE PELAKSANAAN}

\section{A. Metode Kegiatan}

Pelaksanaan Iptek pada masyarakat ini adalah workshop pembelajaran Bahasa Jepang praktis dan pengenalan dan kebudayaan Jepang Oshogatsu dengan menggunakan metode pembelajaran active learning dengan menggunakan multimedia. Kegiatan ini bertujuan untuk membekali pengetahuan pembelajaran bahasa Jepang praktis dan huruf Jepang yang efektif. Sehingga ketika timbul permasalahanpermasalahan dalam proses pembelajaran para pengajar dapat mengatasi. Berdasarkan permasalahan di atas sehingga workshop bagi Generasi muda yang ada didesa Koya Kabupaten Minahasa

\section{B. Prosedur Pelaksanaan}

Pengajaran Bahasa Asing seperti bahasa Jepang misalnya, merupakan salah satu mata ajaran bahasa di pengajaran tinggi atau di sekolah menengah, hasilnya sampai saat ini masih seperti pendahulu, yang mana aplikasinya tidak menunjukan hasil yang memuaskan. Untuk hal tesebut, maka teknologi informasi mencoba masuk dalam proses pengajaran tersebut melalui para pengajar. Adapun manfaat yang diharapkan adalah memiliki konsep dan metode belajar bahasa asing yang inovatif dan memberikan implikasi metodologis serta tehnik yang dipandang berguna bagi proses pembelajaran dan pengajaran bahasa asing.

Kegiatan visualisasi seperti ini diprediksi akan mempermudah pemahaman mahasiswa terhadap contens yang diajarkan dan secara psikologis multimedia mampu memberikan tingkat kebermaknaan yang lebih tinggi dengan dukungan kemudahan pemahaman dan rasa senang ketika proses belajar berlangsung. Unsur kebermaknaan dan rasa senang merupakan elemen utama dalam pembelajaran yang baik Cornor, (1997:83). Sedangkan menurut Philips (1997:14) dengan adanya multimedia pengajar dapat menggalakkan sistem pembelajaran yang kooperatif dan interaktif antara pembelajar dan pengajar. Dengan pembelajaran Bahasa Jepang model teknologi informasi ini akan mengantar peserta didik pada pengenalan model pembelajaran yang menarik dan inovatif, serta memberikan pengetahuan dan nilai tambah bagi peserta didik. Melalui proses pembelajaran ini peserta didik 
dibimbing dan dituntun mengenal modernisasi alam kehidupannya, aktivitas serta pengenalan dunia sekitarnya. Dikatakan demikian karena melalui tehnologi informasi mereka akan memperoleh pengalaman pembelajaran berupa belajar sambil rekreasi, belajar sambil bermain, belajar sambil mengenal hal baru, belajar dengan tehnologi, dan belajar dengan menerima dan memberi komentar praktis dan praktek ketrampilan berkomunikasi. Yang ditawarkan melalui proses ini adalah peserta didik mempelajari bahasa Jepang praktis dan pengenalan budaya Oshogatsu. Proses pencapaiain tujuan pengajaran Bahasa Jepang dengan model ini diharapkan dapat memberikan manfaat

\section{HASIL DAN PEMBAHASAN}

Kegiatan pembelajaran Bahasa Jepang praktis Ddan penegenalan budaya Jepang Oshogatsu pada Generasi muda desa Koya Kabupaten Minahas . dilaksanakan pada tanggal 11 Mei 2019 . Metode yang digunakan dalam kegiatan pembelajaran Bhasa Jepang praktis ini yang dilaksanakan dengan menggunakan metode Active learning dengan pokok permasalahan yang disesuaikan dengan tujuan yang ingin dicapai adalah yaitu metode active learning dengan menggunakan multimedia.

Materi-Materi yang disajikan adalah sebagai berikut:

\section{Oshogatsu}

Oshogatsu (お正 月 ) 'tahun baru' merupakan salah satu perayaan tahunan yang sangat penting dan yang paling ditunggu-tunggu oleh masyarakat Jepang. Oshogatsu berlangsung di tanggal 1-3 Januari. Pada tanggal ini bank, kantor pemerintahan, dan hampir semua perusahaan dan toko di tutup sehingga liburan ini menjadi kesempatan bagi warga Jepang untuk berkumpul bersama keluarga untuk merayakan tahun baru.

Dalam perayaan nenchu gyoji ini, terdapat berbagai tradisi yang dilakukan oleh orang Jepang. Tradisi-tradisi tersebut mulai dilakukan sejak dua minggu terakhir pada bulan desember yaitu : oosoji ( 大掃除) 'pembersihan', pemasangan kazari ( 飾り) 'hiasan', pembuatan osechi ryori (おせち料理) 'makanan khusus tahun baru', mochitsuki ( 餅搗き) 'pembuatan mochi', mengirim nengajo (年賀状) 'kartu tahun baru', joya no kane (除夜の $\stackrel{\text { かね }}{\text {,鐘) }}$ 'pembunyian lonceng menjelang tahun baru' dan toshikoshisoba (年越しそば 蕎麦) 'makan soba di malam tahun baru'.

Ada tiga jenis pembersihan yang dilakukan, yaitu oharai, misogi, dan imi. Kemudian hiasan yang dipasang di berbagai tempat pada saat Oshogatsu adalah shimenawa, kadomatsu, kagami mochi, 
kirigami, dan miki no kuchi. Selain itu tradisi lain yang dilakukan pada saat gantan ( 元旦 ) 'hari pertama tahun baru' yaitu: hatsumode (初詣 ) 'kunjungan pertama ke kuil' dan memberikan otoshidama (お としだま ,年玉) 'angpao' pada anak-anak.

\section{Tradisi-tradisi menjelang Oshogatsu}

\section{Oosoji}

Oosoji (大掃除) merupakan kegiatan

pembersihan secara besar-besaran yang dilakukan sebelum menyambut tahun baru. Berbeda dengan bersih-bersih pada umumnya, karena pada saat Oosoji orang Jepang membersihkan hingga ke tempattempat yang biasanya sangat sulit terjangkau seperti kolong tempat tidur dan belakang lemari. Dan angkat mengangkat lemari, menggeser tempat tidur dan sofa pun sudah jadi bagian dari Oosoji ini.

Menurut Sudjianto (2002:81), oosoji adalah kegiatan pembersihan secara besarbesaran yang dilakukan menjelang oshogatsu. Oosoji tidak hanya dilakukan di rumah-rumah, tapi juga di kuil, gedung sekolah, perkantoran, dan tempat lain. Kegiatan pembersihan yang dilakukan yaitu meliputi menyapu, mengepel, serta mengelap seisi rumah untuk menghilangkan seluruh debu dan kotoran yang ada. Biasanya semua orang ikut terlibat dalam kegiatan ini.

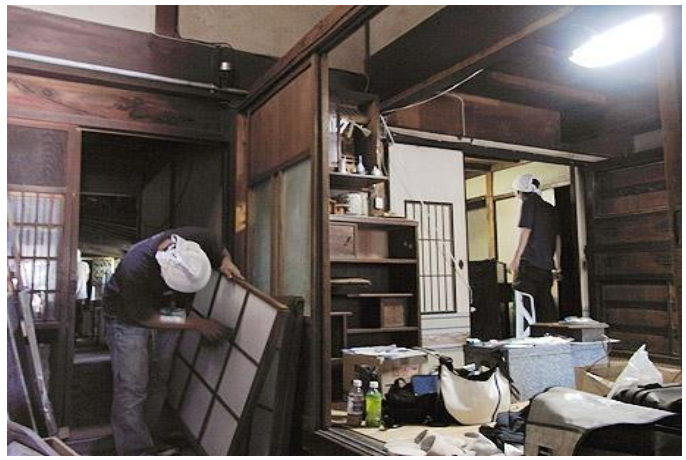

Gambar 4.2.1 Oosoji (sumber: geocities.co.jp)

Menjelang Oshogatsu

(お

しょうがつ

,正月) semua anggota keluarga terlihat sibuk melakukan pembersihan. Pembersihan dilakukan secara menyeluruh di semua sudut rumah mulai dari ruang tamu, kamar tidur, kamar mandi, dapur sampai benda-benda kecil seperti lampu dan hiasan rumah. Jika menyisakan debu atau kotoran dipercaya dapat menghambat datangnya rejeki dan keberuntungan di tahun depan. Selain pembersihan tempat, pembersihan jiwa juga dilakukan yaitu dengan membayar semua hutang dan menyelesaikan segala urusan atau masalah. Hal ini bertujuan supaya mendapat keberuntungan di tahun yang akan datang.

\section{Pemasangan Kazari}

\section{Shimenawa}

Shimenawa ( 注連縄 $)$ merupakan tali atau tambang yang terbuat dari jerami yang dijalin sehingga membentuk hiasan, yang digantung secara melintang di depan gerbang atau pintu masuk. Pada shimenawa biasanya sering ditambahkan shide, yaitu kertas berbentuk zig-zag yang sering 
digunakan dalam ritual Shinto. Shimenawa dipercaya dapat melindungi dari hal-hal negatif atau ketercemaran.(Brandon dan Stephan,1994 : 51)

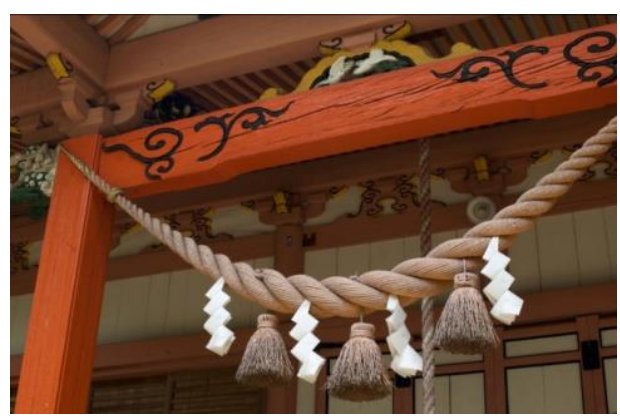

Gambar 4.2.1 Shimenawa (sumber: flickr.com)

Shimenawa merupakan salah satu hiasan tahun baru yang terbuat dari dua buah jerami yang dililitkan. Istilah shimenawa berasal dari fakta bahwa tali (nawa) sangat umum dipakai untuk menandai kepemilikan suatu wilayah. Sementara itu, kata shime berasal dari kata shimeru (占める) yang

berarti menduduki atau memiliki.

Shimenawa yang dipasang dalam perayaan oshogatsu memiliki makna suatu pemisahan hal baik dari hal yang buruk. Shimenawa yang dipasang dalam perayaan oshogatsu dijadikan sebagai simbol pengusir kekuatan jahat atau jimat untuk penolak bala. Tujuannya supaya setiap orang mendapatkan keselamatan dan perayaan oshogatsu dapat berjalan dengan lancar.

\section{Kadomatsu}

Kadomatsu ( 門松) berasal dari kata kado ( 閏 ) berarti pintu masuk dan matsu (
まつ

松) berarti pohon pinus. Menurut Brandon dan Stephan (1994:64), Kadomatsu adalah dekorasi tradisional oshogatsu yang terbuat dari rangkaian bambu, batang pohon cemara, dan ranting pohon plum, yang biasanya diletakkan di depan serambi atau pintu rumah. Selain itu, juga dipasang di depan pertokoan, sekolah, maupun perkantoran.

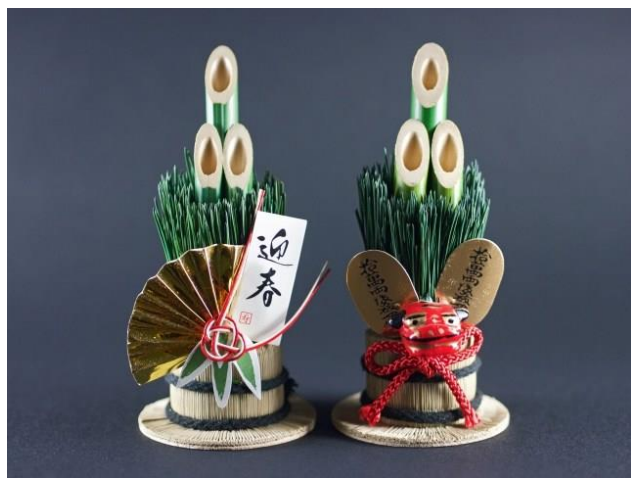

Gambar 4.2.2 Kadomatsu (sumber: tadaimajp.com)

Kadomatsu adalah hiasan dari bambu dan pohon pinus yang dirangkai menjadi satu lalu diletakkan di sebelah kiri dan kanan pintu masuk rumah sebagai tanda datangnya Dewa Tahun Baru yang disebut Toshigami-sama. Dalam keyakinan Shinto, pada saat tahun baru arwah leluhur dalam bentuk Toshigami-sama pertama-tama akan mengunjungi rumah yang dulu mereka tinggali melalui matsu segar (dedaunan pinus) di kadomatsu dan tinggal di kadomatsu untuk sementara selama perayaan oshogatsu. Oleh karena itu, kadomatsu yang dipasang pada saat 
oshogatsu dijadikan simbol tempat tinggal Toshigami-sama.

\section{Kagamimochi}

Kagamimochi ( 鏡 餅) dalam arti harfiah berarti mochi cermin. Sakurai (1991:46)

$$
\text { mengatakan }
$$

bahwa,

Kagamimochi adalah dekorasi khas oshogatsu yakni mochi berbentuk bundar pipih, yang disusun bertingkat dengan ukuran terbesar di bawah dan terkecil di atas. Mochi ini disebut sebagai kagamimochi karena bentuknya yang menyerupai cermin. Dalam bahasa Jepang, kagami berarti cermin.

Kagamimochi adalah dekorasi interior yang diletakkan di atas meja, tidak seperti shimekazari dan kadomatsu yang ditampilkan di luar rumah. Kagamimochi terdiri dari tumpukan dua buah mochi berbentuk bulat pipih yang melambangkan tahun lama dan tahun baru yang diletakkan pada sebuah nampan kayu. Di atas tumpukan mochi biasanya diberi hiasan jeruk.

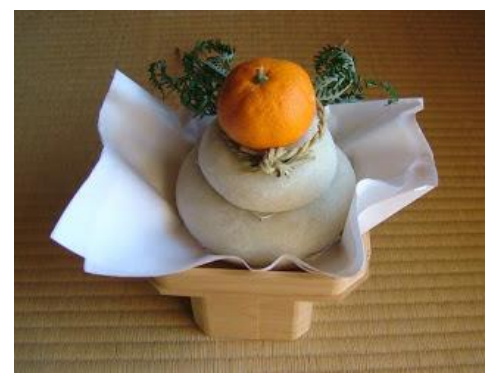

Gambar 4.2.3 Kagami Mochi atau Osonae Mochi (sumber: fingerlickin.com)

Kagamimochi dianggap sebagai benda yang sakral dan dijadikan sebagai lambang hidangan untuk para dewa supaya dewa bersedia datang pada saat Oshogatsu. Hal ini dikarenakan bentuk kagamimochi yang bulat dan pepat menyerupai bentuk kaca tradisional Jepang yang dijadikan sebagai simbol dewa tertinggi ajaran Shinto. Kagamimochi dipercaya mengandung kekuatan Kami di dalamnya. Oleh karena itu, kagamimochi juga sering disebut dengan chikaramochi, yang berarti "mochi kekuatan". Setelah perayaan tahun baru selesai, mochi tersebut dipotong untuk dimakan bersama-sama oleh seluruh anggota keluarga, karena dipercaya orang yang memakan mochi tersebut akan mendapatkan kekuatan kami dari chikaramochi tersebut.

\section{Kirigami}

$$
\text { Kirigami ( 切り 紙 ) merupakan }
$$

salah satu variasi dari kerajinan origami. Berasal dari kata "kiru" yang artinya memotong, dan "kami" yang artinya kertas. Kirigami juga disebut kirie (切り絵) yang berasal dari kata "kiru" (memotong) dan "e"(kertas). Origami merupakan kerajinan kertas lipat yang terlebih dahulu dikenal di masyarakat luas. Seni kerajinan ini berasal dari Jepang. Pada kerajinan origami selain dijadikan sebagai bentuk ritual ataupun sebagai sarana untuk memohon kepada dewa, ada pula sebuah mitos yang menyertainya yaitu apabila membuat kerajinan kertas burung bangau akan 
mendatangkan kebaikan dan permintaannya sampai ke langit. Itulah sebabnya kerajinan origami populer di Jepang bahkan sampai ke tanah Asia dan Eropa.

Kirigami merupakan pengembangan dari seni kerajinan origami. Kerajinan ini merupakan kerajinan yang berasal dari Cina. Kerajinan menggunting kertas ini dibawa oleh orang-orang Jepang yang melakukan perjalanan ke Cina untuk mempelajari agama Budha.

\section{Osechi Ryori}

Osechi Ryori (おせち料理) adalah makanan khusus yang tidak bisa dihilangkan dalam perayaan tahun baru di Jepang. Dalam bahasa Jepang, istilah "Osechi" dulunya berarti pergantian musim yang dikenal dengan sebutan "sechi-nichi" atau “sekku”(節供). Sejak zaman dulu awal tahun baru merupakan salah satu hari pergantian musim (sechi-nichi) untuk merayakan kepulangan dewa padi ke gunung. Osechi ryori (おせち料理 ) sudah ada di Jepang kira-kira sejak seribu tahun yang lalu, diturunkan dari generasi ke generasi dan masih tetap ada sampai sekarang ini. Biasanya orang Jepang membuat Osechi ryori (おせち料理) sebelum tahun baru dan menyelesaikannya sebelum malam tahun baru sehingga mereka mempunyai makanan untuk beberapa hari tanpa harus memasak karena hampir semua toko di Jepang tutup pada waktu Oshogatsu (おしょうがつ

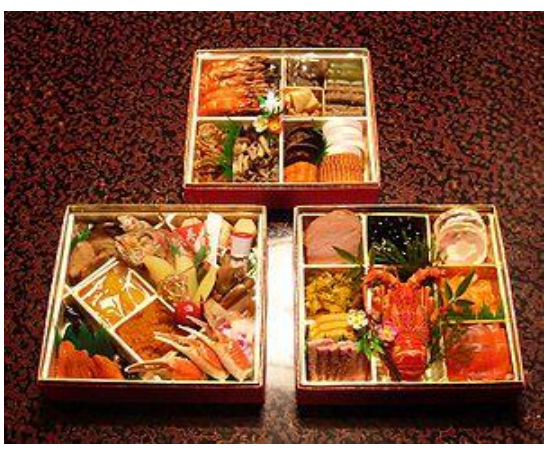

Gambar 4.2.3.1 Osechi Ryori (sumber:Wikipedia) Osechi ryori（おせち料理） terdiri dari berbagai macam masakan. Macam-macam masakan tersebut dimasukkan dan dikemas ke dalam Juubako ( 重箱こ ). Masakan- masakan

\section{KESIMPULAN DAN SARAN}

\section{Kesimpulan}

1. Kegiatan pengabdian pada masyarakat dalam bentuk pelatihan bahasa Jepang praktis dan pengenalan Budaya Oshogatsu pada para generasi muda desa koya Kabupaten Minahasa telah berhasil dilaksanakan dengan baik

2. Pelaksanaan pelatihan ini telah mencapai tujuan yang dilaksanakan karena semua peserta dapat menguasai dan menggunakan bahasa Jepang sederhana pengenalan Budaya Oshogatsu. 
3. Oshogatsu berlangsung pada tanggal 1 sampai 3 Januari. Sejak dua minggu terakhir pada bulan desember terdapat tradisi-tradisi yang dilakukan untuk menyambut perayaan ini yaitu: joya no kane 'pembunyian lonceng menjelang tahun baru', toshikoshisoba 'makan soba di malam tahun baru', oosoji 'pembersihan', mochitsuki 'pembuatan mochi', pemasangan kazari 'hiasan', pembuatan osechi ryori 'makanan khusus tahun baru', hatsumode 'kunjungan pertama ke kuil', mengirim nengajo 'kartu tahun baru' dan memberikan otoshidama 'angpao' pada anak-anak. pada saat Oshogatsu anak-anak menerima Otoshidama dari orang dewasa (orang tua, kerabat atau tetangga). Otoshidama adalah sebutan untuk amplop berisikan uang yang diberikan orang dewasa kepada anak-anak pada saat tahun baru di Jepang. Biasanya amplop yang digunakan yaitu amplop putih polos disertai pesan dari orang yang lebih tua kepada yang lebih muda. Amplop kecil khusus untuk otoshidama disebut pochi-bukuro atau otoshidama-bukuro.

\section{Saran}

Dari kegiatan pengbdian yang telah dilakukan maka penulis dapat mengajukan beberapa saran yaitu sebagai berikut:

1. Dikarenakan dalam penelitian ini masih terdapat banyak kekurangan, maka diperlukan adanya penelitian lanjutan untuk melengkapi dan menyempurnakan hal-hal yang berkaitan dengan Oshogatsu.

2. Dapat dijadikan suatu referensi untuk mempelajari dan memahami tentang berbagai tradisi yang dilakukan pada saat Oshogatsu.

\section{KEPUSTAKAAN}

Ajip Rosidi. 1981. Mengenal Jepang. Jakarta: Pusat Kebudayaan Jepang

Alan Campbell \& David S.Noble.( 1995). "Osechi ryori". Japan: An Illustrated Encyclopedia. Tokyo: Kodansha

Astuti, Yulianti. 2016. Kue Mochi: Demi Harapan Indah di Tahun Baru. Jakarta: PT Bina Komunika Asiatama

Bastomi, Suwaji. 1985. Kebudayaan Apresiasi Pendidikan Seni. Semarang: Ikip Semarang Press

Brandon, R. M., dan Barbara B.S. (1994). Spirit and Symbol the Japanese New Year. Hawaii: Honolulu Academy of Arts.

Coomans, Mikhail. 1987. Manusia Dayak: Dahulu, Sekarang, Masa Depan. Jakarta: PT.Gramedia 
Depdikbud. 1988. Kamus Besar Bahasa Indonesia. Jakarta: Balai Pustaka

Eigo de Hanasu. 1996. Nihon no Kokoro. Tokyo: Kodansha International Ltd Gilhooly, Helen. 2002. World Cultures : Japan. London: Hoder Headline

Hadi, Upik. 2011. Oshogatsu. Bandung: IPB

Herskovits,Mevillle J.1948. Man and His Work: The Science of Cultural Anthropology. New York: Knopf

Hori, Ichiro. 1968. Folk Religion in Japan. Tokyo: University of Tokyo Press

Kaneda, Ichiharuhiko dan Ikeda, Yasaburo. 1990. Gakken Kokugo Daijiten Dainihon. Tokyo: Gakushu Kenkyusha
KIRSJL. 1992. Nihon no Kurashi Jyuunikagetsu. Japan: Kyobundoh

Kodansha. 2003. The Kodansha Bilingual of Japan. Tokyo: Bunkyo-Ku

Kodansha. 1983. The Kodansha Bilingual Encyclopedia of Japan Volume 7. Amerika: Kodansha Amerika Inc Koentjaraningrat. 1985. Pengantar Ilmu Antropologi. Jakarta: Aksara Baru 1993. Kebudayaan Mentalitas dan Pembangunan. Jakarta: Gramedia Pustaka 1996. Pengantar Antropologi I. Jakarta: Rineka Cipta 